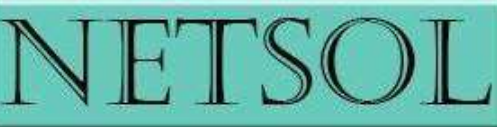

NEW TRENDS IN SOCIAL AND LIBERAL SCIENCES

An Interdisciplinary Journal

http://www.netsoljournal.net/

Volume 5, Issue 2, pp.30-45, Fall 2020

https://doi.org/10.24819/netsol2020.06

Date Submitted: May 5, 2020

Date Accepted: October 26, 2020

\title{
Lincoln and Education
}

\section{Rolando Avila, University of Texas-Rio Grande Valley and}

\section{Anita Pankake, Retired Professor, University of Texas-Rio Grande Valley}

Abstract: The current norm of compulsory formal schooling includes a system in which schools teach state mandated curriculum, parents are held legally responsible to assure their children attend school until they reach a certain age, and students are confined within set class meeting times and set locations during their schooling years. The two terms, education and schooling, have been increasingly used synonymously. Our assertion here is that education is a more inclusive term than schooling. More importantly, using Abraham Lincoln as a biographical model, we argue that a good education can be achieved in different ways.

Key Words: Biography, History, Abraham Lincoln, Education, Schooling, Pedagogy

\section{Introduction}

Parents are often heard to say they want their children to get a good education. While they use the word education, they are generally referring to compulsory formal schooling. The current norm of compulsory formal schooling includes a system in which schools teach state mandated curriculum, parents are held legally responsible to assure their children (until they reach a certain age) attend school, and students are confined within set class meeting times and set locations during their schooling years. The two terms, education, and schooling, have been increasingly used synonymously. Our assertion here is that education is a more inclusive term

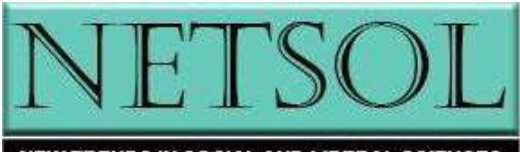

NEW TRENDS IN SOCIAL AND LIBERAL SCIENCES 
than schooling. More importantly, we will argue that a good education can be achieved in different ways.

Slowly, conversations regarding approved options for educating America's children and youth have increased. Traditional public school districts with specific specialized programs and campuses have been the most common paths. Increasingly, charter schools, private schools, online/virtual schools and home schooling have emerged as alternatives to the traditional public school setting. Advertisements for online schooling have become increasingly frequent on both radio and television. As various accountability systems are mandated to determine student achievement levels, as controversies over how to finance schools and schooling increase in intensity, as concerns for ways to assure the safety of students multiply, and as parent concerns regarding fit between an individual child and the schools' organization increase, other options for securing a quality education merit additional consideration.

Two currently best-selling books, Educated (Westover, 2018) and Where the Crawdads Sing (Owens, 2018), focus on young women raised in environments where formal schooling was either intentionally avoided or not easily accessed. Even so, both women found other means of learning. In one story the young woman, raised in isolated conditions, relocates, and ultimately attends and graduates from some of the world's most prestigious schools. In the other story, the young woman learns from her environment and becomes a famed expert on the marshes of North Carolina. Both of these women were highly educated, but not all or even most of their education came from formal schooling. These contemporary examples help form the context for all that follows in this article.

Assuming the options for schooling in the United States continue to expand, we assert that distinguishing between schooling and education is of increasing importance. As various models for educating individuals (children and adults) are developed, a movement away from the "one size fits all" thinking encompassed in the current public school system and an acceptance of multiple means for individuals to become educated will expand.

In illustrating the possibility of this new perspective, we offer a look at an historical educated figure who had little schooling yet is admired for his thinking, writing, principles, and leadership. Our purpose is to explore through biography, the actions and experiences of Abraham Lincoln that provided him a quality education, little of which was attained through formal schooling. How is it that Lincoln learned so much and developed such a depth of wisdom without experiencing more than a year of formal schooling either as a youth or young adult --- no high school graduation, no college courses at all?

We use biography to illuminate Lincoln's learning path which contained little schooling but rich educational opportunities. Consequently, our first task is to offer information to assist readers in understanding biography as a method that can be used in achieving our purpose. In the following pages, our first undertaking will be to describe biography and how it was used in this exploration. Next, we offer our justification for selecting Lincoln as our example. We rely heavily on what others have written about Lincoln and words from Lincoln himself to describe various aspects of his educational journey, including his family and personal characteristics, all

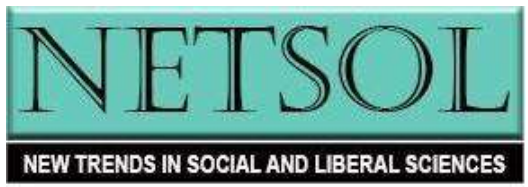


of which shaped his willingness to pursue his education despite his lack of schooling. Finally, we make a sincere attempt to use the information presented to proffered answers to the questions we initially posed. We also offer additional questions that have emerged based on our organization and presentation of information.

\section{Method: Historical Biography}

Historians employ various rigorous methods and approaches to interpret the past. Some scholars prefer to interpret history through a quantitative lens by examining the general trends of groups of people. Data bases of various kinds (e.g. census data) assist these researchers in searching for and identifying certain patterns. On the other hand, writers of historical biography focus on the life and experiences of one individual. According to award-winning historical biographer, Stephen B. Oates:

Biography is useful because it encompasses the universal in the particular. It is a focus that allows both the writer to narrow his field to manageable dimensions and the reader to more easily comprehend the subject. Given too wide a scope, the central theme wanders, becomes diffuse, and loses shape. One does not try for the whole but for what is truthfully representative (Oates, 1986, p. 94).

In truth, both approaches are legitimate and complement each other. The main difference, however, is that while the quantitative approach categorizes groups of people according to their similarities, the historical biography approach highlights an individual's uniqueness. Although most people share certain common experiences, "biography, in short, celebrates the fact that no two people have ever been exactly alike," and "we are all different even as we share our common humanity" (Oates, 1990, p. 7). ${ }^{1}$

\section{Why Abraham Lincoln?}

Although there are other examples of successful individuals who had little or no formal education, we chose to showcase Lincoln in this study, because, with very little formal schooling, he rose to and was successful in the highest leadership position in American society.

\footnotetext{
${ }^{1}$ Since Lincoln's assassination, many Lincoln myths have arisen. This myth-building has sometimes resulted in a Lincoln image that is larger-than-life. However, when we remove the lens of hero worship, we see an adult Lincoln who was, in fact, gifted with intellectual prowess, but in no way a natural-born genius. Young Lincoln was not a natural-born reader, writer, or mathematician. Instead, he developed most of his intellectual gifts over time with practice and repetition. Self-motivation and very hard work were a key component of his success. As one of his Kentucky schoolmates observed, Lincoln "was not a brilliant boy - but he worked his way by toil: to learn was hard for him, but he walked slowly, but surely" (Wilson \& Davis, 1998, p. 453-454). How smart was he? The answer to that question will vary depending on what historian one consults. But when we view Lincoln as human (like one of us) we can use his biographical example to teach us without the threat of the negation of broad applicability. We acknowledge some of Lincoln's environmental factors important to his learning, his stepmother, and his colleagues, among others. The discussion of "nature vs. nurture" for human development is a longstanding one and has yet to be settled. The information presented does not argue one or the other.
}

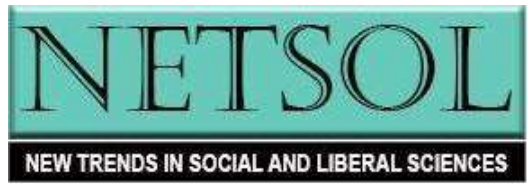


Historians have estimated that Lincoln had about one year of formal schooling. In fact, Lincoln was among the American Presidents with the least formal schooling (Neely, 1982), and yet, is considered by many historians to have been our greatest president (Merry, 2012). It is unlikely that only about one year of formal schooling equipped Lincoln for the role of chief executive of the United States of America. If formal schooling was not the source of Lincoln's preparation for this role, how did he become the highly educated man who led the nation through one of its most tumultuous periods?

\section{Review of Literature}

Very few books were available and little to no formal education was typical in the 1800s along American frontier regions where Lincoln grew up. How did Lincoln rise above these stark limitations? He read as much as he could and developed his mathematical skills. For this reason, many authors have primarily focused on Lincoln's reading and mathematics habits. Biographer Albert J. Beveridge's Abraham Lincoln, 1809-1858, for example, provides one of the best accounts of young Lincoln's reading habits (Beveridge, 1928). Shorter interpretative accounts include Douglas L. Wilson's "What Jefferson and Lincoln Read," which compares the reading habits of Thomas Jefferson and Abraham Lincoln (Wilson, 1991). However, the definitive source for Lincoln's reading habits, including a list of books he read, is Three Presidents and Their Books: The Reading of Jefferson, Lincoln, \& F.D. Roosevelt (Bestor, Mearns, \& Daniels, 1963). Lloyd A. Dunlap's "Lincoln's Sum Book" elaborates on Lincoln's skill with numbers (Dunlap, 1959), while Maurice Dorfman's "Lincoln's Arithmetic Education: Influence on His Life" makes a good case for the influence of mathematics education on Lincoln's success in his various careers (Dorfman, 1966).

Most of what writers know about Lincoln's education can be found in his own written and spoken words and in the recollections of his contemporaries. The largest collection of Lincoln's writings is Roy P. Basler's The Collected Works of Abraham Lincoln (Basler, 19531955). An authoritative collection of Lincoln's spoken words has been edited by Don E. Fehrenbacher and Virginia Fehrenbacher in Recollected Words of Abraham Lincoln (Fehrenbacher, 1996). Shortly after Lincoln's assassination, William H. Herndon (Lincoln's former law partner) traveled to Lincoln's former towns of residence and interviewed many of Lincoln's contemporaries. Douglas L. Wilson and Rodney O. Davis have edited Herndon's collection of recollections in Herndon's Informants (Wilson \& Davis, 1998).

The Inner Life of Abraham Lincoln: Six Months at the White House by F. B. Carpenter is among a handful of valuable first-hand accounts of President Lincoln's actions. First published in 1866, one year after Lincoln's death, it has been reprinted a number of times. In the introduction to the 1995 reprinting, Historian Mark E. Neely, Jr. writes that "Carpenter proves to have been an accurate observer with a reliable memory for what he saw and heard while painting portraits in the executive mansion" (Carpenter, 1995, v). This makes Carpenter's book an exception to most reminiscence-type literature. In fact, Neely regards the book as indispensable: "All Lincoln sources must be used with care, but, unlike many of them, Carpenter's book must

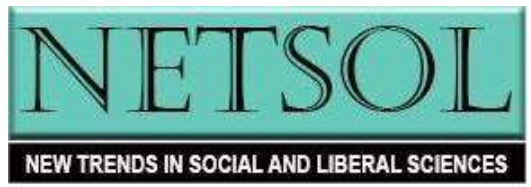


be used" (Carpenter, 1995, xi). Lincoln Historian David Herbert Donald included a succinct yet informative chapter on Lincoln's education ("Education Defective: Lincoln's Preparation for Greatness") in his 2001 edition of Lincoln Reconsidered: Essays on the Civil War Ear (Donald, 2001). Lastly, Louis A. Warren (director of the Louis A. Warren Lincoln Library Museum, editor, and author) sheds light on the importance of Lincoln's early period in Lincoln's Youth, Indiana Years, Seven to Twenty-one, 1816-1830 (Warren, 1991). According to Warren, these often overlooked and seldom understood early years shaped Lincoln into the man that he became. Lincoln's character and even his career path was due to his formal and informal education.

\section{Lincoln's Views of Education}

Lincoln valued his own education, and education in general. He felt that Americans should be able to discover for themselves from books about love of country, religion, and moral truths. In 1832, Lincoln delivered his first political platform, which sheds light on his views regarding the importance of education:

Upon the subject of education, not presuming to dictate any plan or system respecting it, I can only say that I view it as the most important subject which we as people can be engaged in. That every man may receive at least, a moderate education, and thereby be enabled to read the histories of his own and other countries, by which he may duly appreciate the value of our free institutions, appears to be an object of vital importance, even on this account alone, to say nothing of the advantages and satisfaction to be derived from all being able to read the scriptures and other works, both of a religious and moral nature, for themselves (Basler, 1953-1955, vol. 1, p. 9).

Lincoln regretted not having a classical college education. In 1861, President Lincoln was shaking hands with Rutgers College students. He leaned over to New York Herald reporter Stephen R. Fiske and commented, "Ah, that is what I have always regretted - the want of a college education. Those who have it should thank God for it" (Fehrenbacher, 1996, p. 160).

\section{Formal Education: Laying the Foundation}

Lincoln attended school a few weeks at a time over several years. However, if all his formal schooling were added together, it would equal a little bit less than one calendar year. Lincoln's teachers included Zachariah Riney, Caleb Hazel, Andrew Crawford, and Azel W. Dorsey. Almost nothing is known about these individuals except for their curriculum. According to Lincoln, his teachers concentrated on teaching him the basics: "readin, writin, and cipherin" (Basler, 1953-1955, vol. 3, p. 511). At school, Lincoln used Dilworth's Spelling-Book and Noah Webster's Old Blue-Back Spelling Book, which were among the few books that his stepmother had brought with her when she joined the Lincoln family.

It is safe to say that Lincoln's formal education, which came to an end when he was fifteen years old, left much to be desired. School facilities were primitive, and teachers often possessed minimal skills. Lincoln joked, "If a straggler supposed to understand Latin, happened

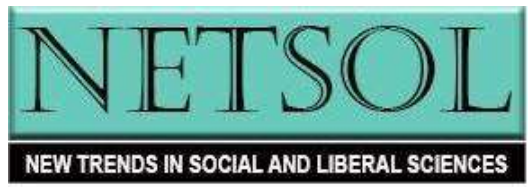


to sojourn in the neighborhood, he was looked upon as a wizard" and was often hired to teach the local children (Basler, 1953-1955, vol. 3, p. 511).

By Lincoln's own assessment, his education was "defective" (Basler, 1953-1955, vol. 2, p. 459). However, his statement must be placed in the proper context. Lincoln's exposure to educational opportunities for a total of one year was, in fact, outstanding compared to the majority of children living in his same circumstances. "On the frontier" and "at that time this was considered a full common-school education - and it was a great deal more than many children received" (Donald, 2001, p. 66).

Lincoln made the statement about his education being defective only after he had served in Congress and began to feel uneducated compared to his colleagues who had graduated from colleges. Lincoln felt that the curriculum that he had been exposed to had been too basic. However, he acknowledged that he learned the basics well. He later wrote, "I did not know much. Still somehow, I could read, write, and cipher" (Basler, 1953-1955, vol. 3, p. 511).

\section{Informal Education: Building on the Foundation}

Lincoln recalled moving from Kentucky to the Spencer County, Indiana frontier wilderness with his family when he was eight years old. He stated, "We reached our new home about the time the state came into the Union. It was a wild region, with many bears and other wild animals, still in the woods. There I grew up" (Basler, 1953-1955, vol. 3, p. 512). Both of Lincoln's parents were illiterate. However, "while Thomas and Nancy Lincoln had never had the privilege of a formal education, they were anxious that their children should take advantage of every opportunity that came their way to get instruction" (Warren, 1991, p. 10). ${ }^{2}$ This went against the norm. Many people from that region saw literacy as a luxury with little use in the harsh wilderness environment the families faced every day. There was hard manual work to be done, and some people judged reading as laziness. Lincoln wrote, "There was absolutely

\footnotetext{
2 Some historians believe that Thomas, Lincoln's father, was to some extent averse to Lincoln's educational efforts. However, as the Warren quote above illustrates, other historians disagree with this assessment. Interviews conducted after Lincoln's death by William Henry Herndon, Lincoln's law partner, in Kentucky, where Lincoln was born and spent the earliest years of his life, support Warren's view. Additionally, since Lincoln did, in fact, achieve some level of education during these early years, the opposing view holds that Lincoln's educational success must have been solely due to his stepmother's support. It is true that his stepmother brought some books with her when she married Thomas and that she supported young Lincoln's educational pursuits. But this does not mean that Thomas's purported "aversion", no matter when it may have developed, was ever a significant barrier to his son's education. Those support this position forget or overlook that young Lincoln went to school before his stepmother entered the picture. In fact, there is evidence that Thomas "took pride in his son's mental precocity" (Hunt, 1986, p. 106). Furthermore, Thomas gifted young Lincoln a book which he greatly cherished and devoured. This was no small matter, since books were rare, which made this an expensive gesture. Many years later, Lincoln recalled how he "was so excited" by the gift, that he "could not eat, and that night he could not sleep" (Donald, 2001, p. 68).
}

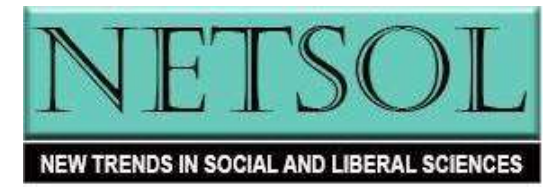


nothing to excite ambition for education" (Basler, 1953-1955, vol. 3, p. 511). However, Lincoln's parents allowed him to self-educate after his chores were done, and he did so with great enthusiasm.

One of Lincoln's neighbors recalled, "While other boys were out...trifling away their time, he was studying books - would sit up late in the night - kindle up the fire - read by itcipher by it" (Wilson \& Davis, 1998, p. 126). In other words, the "defective" schools had provided Lincoln with a strong enough foundation for him to continue to build on, and that is exactly what he did for the rest of his life.

\section{Learning Style}

Lincoln read both indoors and outdoors. While living in New Salem, he would go to the woods so that he could be alone when he read. When he read in town, the public would see him "reading, walking in the streets, occasionally becoming absorbed with his book, would stop and stand for a few moments, then walk on...seemed invariably to reflect and deliberate" (Wilson \& Davis, 1998, p. 498). Indoors, he would "read aloud very often; and frequently assumed a lounging position when reading" (Wilson \& Davis, 1998, p. 90-91). At his home in Springfield, "his favorite way of reading... was lying down on the floor" (Wilson \& Davis, 1998, p. 407).

In 1832, Lincoln borrowed law books from attorney John Todd Stuart in order to study Law. One of his contemporaries, Robert B. Rutledge witnessed Lincoln's habits during this time. Rutledge writes that when Lincoln began to study Law "he became wholly engrossed" (Wilson \& Davis, 1998, p. 426). "I think," he wrote, "he never avoided men until he commenced to study Law" (Wilson \& Davis, 1998, p. 426). In order to be alone, "in the summer season he frequently retired to the woods to read and study" (Wilson \& Davis, 1998, p. 426). According to Rutledge, Lincoln would also "read \& study at late hours after the business of the day was disposed of" (Wilson \& Davis, 1998, p. 426). One Indiana neighbor described Lincoln's reading habits in the following way:

When Lincoln, Abraham and I returned from work, he would go to the cupboardsnatch a piece of corn bread-take down a book-sit down on a chair-cock his legs up high as his head and read...Abraham read constantly when he had an opportunity...Lincoln devoured all books he could lay hands on: he was a constant and voracious reader.... He would go out in the woods \& gather hickory bark-bring it home \& keep a light by it and read by it-when no lamp was to be had...." (Wilson \& Davis, 1998, p. 455).

Lincoln was not content to neglect the welfare of his body while feeding his mind. After years of wielding an axe on the frontier, he had become quite strong. In the summer of 1862, President Lincoln accompanied some gentlemen to a Washington Navy yard to witness the performance of some new guns. While on board a steamer he spotted some axes and grabbed one. As the presenter explained the merits of two new weapons, Lincoln interrupted: "Gentlemen, you may talk about your Raphael repeaters and eleven-inch Dahlgrens; but here is an institution which I understand..." (Carpenter, 1995, p. 113). Lincoln then showcased his physical strength by holding the axe "out at arm's length by the end of the handle, or helves, as

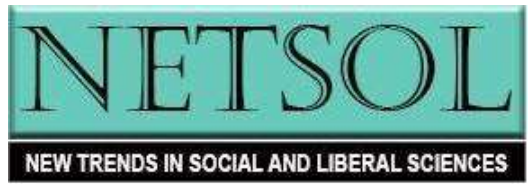


the wood-cutters call it - a feat not another person of the party could perform, though all made the attempt" (Carpenter, 1995, p. 114). On another occasion, the president was visiting wounded troops at local hospitals and a surgeon expressed concern that Lincoln's arm might go lame from "so much hand shaking" (Carpenter, 1995, p. 288-189). Lincoln responded to the doctor's comment by demonstrating his arm strength. He took up "a very large, heavy axe which lay there by a log of wood," and chopped wood "vigorously for a few moments, sending chips flying in all directions" (Carpenter, 1995, p. 189). Then, he "extended his right arm to its full length, holding the axe out horizontally, without it even quivering as he held it" (Carpenter, 1995, p. 189). A witness reported that "strong men who looked on-men accustomed to manual laborcould not hold the axe in that position for a moment" (Carpenter, 1995, p. 189). Besides benefitting physically from the work detail of splitting rails with an axe on the frontier, as a young man in New Salem, he also engaged in the recreational physical activity of wrestling. He practiced the sport until he became very good at it. One friend recalled, "Mr. Lincoln was fond of wrestling, in which he excelled" (Wilson \& Davis, 1998, p. 91). In fact, his reputation as a formidable wrestler became well known on the frontier.

Although Lincoln had not benefitted from formal school sponsored field trips, when he was about nineteen years of age in 1828, he left his father's farm and made a flatboat trip to New Orleans where he sold farm produce and earned his first dollar. The experience of benefitting from the fruits of his labor meant a great deal to him, and for years to come he would happily tell the story. He returned to New Orleans by flatboat in 1831, when he was about twenty-one years of age and, for the first time, saw slaves in chains and on the selling block. For Lincoln, the abstract concept of slavery became horrifically real. Years later, he recalled, "there were, on board, ten or a dozen slaves, shackled together with irons. That sight was a continual torment to me..." (McPherson, 2009, p. 4). In short, these trips changed Lincoln forever by widening his horizons.

\section{Listening to Recall}

Historian David Herbert Donald describes the common school room conditions: "Teaching methods were dictated by the absence of blackboards, chalk, and textbooks and by the scarcity of paper. These were often called, 'blab' schools, because the teacher, holding the only copy of the text in his hand, would read a line aloud, and all the children would repeat it in chorus" (Donald, p. 65).

One Indiana neighbor recalled how Lincoln applied the school "blab" technique at home: "He would hear sermons preached - come home - take the children out — get on a stump or log and almost repeat it word for word." (Wilson \& Davis, 1998, p. 106). Another neighbor corroborated: "Abe...when he was 15 years of age...could hear a sermon... and repeat it accurately..." (Wilson \& Davis, 1998, p. 104).

\section{Mathematics with Application}

Lincoln continued to work on his math skills long after his formal schooling ended. Fortunately for researchers, a copy of Lincoln's sum book still exists. It reveals that "by the age

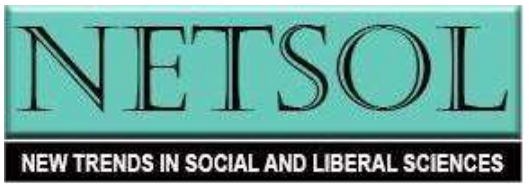


of seventeen, Lincoln had a good grasp and deep understanding of elementary arithmetic" (Durfman, 1966, p. 79). His math skills paid off after he left home. His skills qualified Lincoln to become a shopkeeper, and when he ran a store, he developed a reputation of honesty down to the penny. Later, he used his math knowledge to teach himself trigonometry and set off to be a surveyor. He surveyed public roads and surveyed plans for the towns of "New Boston, Bath, Petersburg, and Huron" (Donald, 2001, p. 69). After successfully settling a number of land disputes, he gained a reputation for accuracy. In 1849, Lincoln again applied math skills to develop a plan to equip ships with buoyant chambers to keep them from running aground. Although his device was never employed, he became "the only President ever to own a patent" (Neely, 1982, p. 162).

\section{Reading to Remember and Reflect}

In an address before the Wisconsin State Agriculture Society in 1859, Lincoln stated: "A capacity, and taste, for reading, gives access to whatever has already been discovered by others. It is the key, or one of the keys, to the already solved problems. And not only so, it gives a relish, and facility, for successfully pursuing the [yet] unsolved ones" (Basler, 1953-1955, vol. 3, p. 481). He loved books and he internalized as much as possible from them. Besides the two spelling books that Lincoln used at school, he also had access to five books in the family library. For example, he read the family Bible over and over again. It is not surprising, therefore, that Lincoln's presidential speeches were filled with biblical allusions. Perhaps, his Second Inaugural Address (1865) is the most striking example of his use of biblical themes. He read and memorized Aesop's fables. As an adult, Lincoln often told stories (in Aesop's fable style) to his friends, and he sometimes reasoned out solutions to real world problems with audible stories.

One day, his father bought him a copy of Pilgrim's Progress. He was so excited that "his eyes sparked" and he "could not eat, and that night he could not sleep" (Donald, 2001, p. 68). As president, he often recited passages from memory from Pilgrim's Progress to his friends. The adventures of Sinbad the Sailor and Robinson Crusoe ignited Lincoln's imagination. According to biographer Albert J. Beveridge, "Lincoln remembered all he read" (Beveridge, 1928, p. 73). Beveridge explains, "Lincoln read so thoroughly that he could repeat, word for word, parts that best pleased him. When he came across a passage that struck him he would write it down on boards if he had no paper and kept it there 'till he did get paper, then he would rewrite it, look at it, repeat it" (Beveridge, 1928, p. 77).

Lincoln also borrowed books from his neighbors. Although Lincoln's acquaintances agreed that "he read and re-read all the books he could get hold of," writer Douglas Wilson points out that "given the primitive character of the neighborhood," there were not many books to borrow" (Wilson, 1991, p. 51). In spite of the dearth, the few books that he was able to borrow throughout the years had a great influence on him. For example, he worked on his literacy with an Etymological Dictionary and Kirkham's Grammar Book. His patriotic and industrializing spirit grew after reading books like Grimshaw's History of the United States, Manson Weem's Life of Washington and James Riley's Narrative Life of Franklin. Ethics and

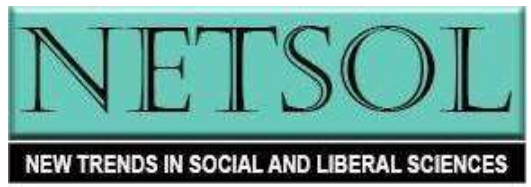


morals were expounded on in the Kentucky Preceptor, while Lincoln studied effective speaking techniques in Lessons in Elocution by William Scott of Edinburgh.

When a neighbor who left his copy of Weem's Life of Washington in the rain no longer valued the damaged book, Lincoln secured it by exchanging two days of work for it. Years later, Lincoln walked for several miles to borrow The Revised Laws of Indiana from Justice of the Peace David Turnham. This was the first law book that Lincoln ever read. It contained a copy of the U.S. Constitution, the Declaration of Independence, the first twelve Amendments, and many Indiana laws. The large volume had more than 500 pages, which Lincoln read and re-read until he had mastered it.

Lincoln was elected the $16^{\text {th }}$ president of the United States in 1860. Most of his time as president was spent dealing with the American Civil War (1861-1865), so he had little time for reading books or newspapers. However, he began the habit of carrying a book of Shakespeare plays, which he read during any free time and often recited his favorite parts of the plays to his acquaintances. During the war, which caused great human suffering and death, Lincoln reflected on Shakespeare's writings as he pondered about the human condition.

F.B. Carpenter spent six months in the White House painting the famous portrait of the writing of the Emancipation Proclamation, and he witnessed Lincoln's growing fondness for Shakespeare plays. On one occasion, Lincoln conversed with Carpenter about Hamlet. Lincoln said, "the soliloquy of the king...always struck me as one of the finest...in the world" (Carpenter, 1995, p. 50). Carpenter writes, "then, throwing himself into the very spirit of the scene, he took up the words" and recited an extremely long passage from memory "with a feeling and appreciation unsurpassed by anything I ever witnessed upon the stage" (Carpenter, 1995, p. 50-51).

\section{Writing with Purpose}

One of Lincoln's neighbors reported on his self-motivation to write at every possible opportunity: "[The] Lincolns had an old grey horse, and it was not able to plow as much as Abe was.... Abe, while the horse rested, had his paper, pen, and ink out in the field and made use of the time while the horse rested. He always put...the time to good advantage" (Wilson \& Davis, 1998, p. 560). Indeed, Lincoln wrote a lot throughout his lifetime. As mentioned above, Basler's Collected Works of Abraham Lincoln represents a major scholarly effort to publish Lincoln's complete writings (Basler, 9 vols., 1953-1955). Practice led to improvement. During the turmoil of war, President Lincoln's writing abilities flourished. By late 1862 he had determined that the only way to save the Union was to free the slaves that resided in the rebelling states. So, in a time before presidential speech writers, Lincoln rose to the occasion by addressing the heated issue of slavery.

In 1863 the largest battle of the Civil War at Gettysburg had left thousands of men dead and a cemetery in the fallen men's honor would be dedicated there. Lincoln was asked to speak, and he agreed. Contrary to the myth that he composed the speech on the train on the way to the ceremony, Lincoln worked hard on the speech for several days. Historian James McPherson

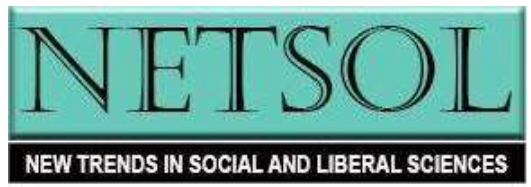


wrote, "The elegant prose poem is constructed of three parallel sets of three images each that are intricately interwoven: past, present, future; continent, nation, battlefield; and birth, death, rebirth" (McPherson, 2009, p. 51). On November 19, Lincoln delivered "the most famous speech in American history" (McPherson, 2009, p. 51). The Gettysburg Address was only 272 words long and took only two minutes to deliver. By the next day when the speech was published in newspapers, many people were able to discern its impressive power. For example, noted orator Edward Everett, the other speaker at the event, wrote to Lincoln, "I should be glad, if I could flatter myself that I came as near the central idea of the occasion, in two hours, as you did in two minutes" (Basler, 1953-1055, vol. 7, p. 25).

Writer Gary Wills points out the revolutionary aims of the short speech. According to Wills, Lincoln changed what America stood for during these two short minutes. When in 1863 Lincoln said that "Four score and seven years ago" (87 years ago) the founding fathers created the nation, he was not referring to the establishment of the nation under the U.S. Constitution, which protected slavery. Instead, mathematically 87 years ago worked out to 1776 . In other words, according to Lincoln, the nation was created with the signing of the Declaration of Independence, which states that "all men are created equal." With a few words, Lincoln changed what America was fighting for and stood for. Wills wrote:

He would cleanse the Constitution.... He altered the document from within, by appeal from its letter to the spirit.... By implicitly doing this, he performed one of the most daring acts of open-air sleight-of-hand ever witnessed by the unsuspecting.... The crowd departed with a new constitution Lincoln had substituted for the one they brought there with them. They walked off...into a different America. Lincoln had revolutionized the Revolution, giving people a new past to live with that would change their future indefinitely (Wills, 1992, p. 38).

When it came time to sign the Emancipation Proclamation, Lincoln's hand was sore from shaking hands at a three-hour reception. McPherson wrote, "Lincoln did not want to sign while his hand was still trembling" because he thought that people would think that he had "hesitated" (McPherson, 2009, p. 64). Lincoln was well aware that he would be remembered for freeing the slaves. It was as if all his efforts had led him to that time and place in history. Lincoln said, "If my name ever goes into history it will be for this act" (McPherson, 2009, p. 64). Then, Lincoln, the son of illiterate parents, signed his name to the Proclamation.

\section{Life-Long Learner}

In 1852, in a eulogy on Henry Clay, Lincoln briefly touched on the topic of the great statesman's informal education: "Mr. Clay's education, to the end of this life, was comparatively limited. I say 'to the end of his life,' because I have understood that, from time to time, he added something to his education during the greater part of his whole life" (Basler, 1953-1955, vol. 2, p. 125). Lincoln's educational experience followed the same pattern. Lincoln explained his informal approach to education in an 1860 short autobiography: "The little advance I now have upon this store of education, I have picked up from time to time under the pressure of necessity" (Basler, 1953-1955, vol. 3, p. 512). In a second autobiographical statement, Lincoln referred to

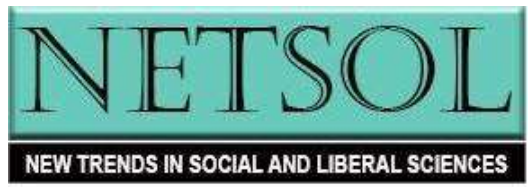


himself in the third person: "He was never in a college or academy as a student.... What he has in the way of education he has picked up... He regrets his want of education, and does what he can to supply the want" (Basler, 1953-1955, vol. 4, p. 63).

During his years as a lawyer, Lincoln continued to expand his education in other disciplines. He discussed politics with Herndon, his law partner. He honed his writing and speaking skills by joining a poetry society and becoming a charter member of the Young Men's Lyceum. In the mid-1850s, Lincoln purchased a set of science books and explained to Herndon: "I have wanted such a book for years because I sometimes make experiments and have thoughts about the physical world that I do not know to be true nor false. I may, by this book, correct my errors.... I can see where scientists...have failed...or can see the means of their success and take advantage of their brains, toil, and knowledge" (Fehrenbacher, 1996, p. 247).

\section{Books and Hard Work}

When it came to the study of law, Lincoln worked hard to achieve his goal. His labors paid off when in 1837 he joined the ranks of practicing attorneys. In 1844, Lincoln set up a law partnership with long-time friend William Henry Herndon. The Lincoln \& Herndon Law Office was very successful and both men became wealthy, because they greatly complemented each other's talents. College educated Herndon was a good researcher while Lincoln was a formidable trial lawyer.

Several aspiring attorneys wrote to Lincoln asking to read law with him or soliciting career path advice. In 1855, for example, Lincoln wrote Isham Reavis:

I did not read with any one. Get the books, and read and study them till, you understand them in their principal features; and that is the main thing. It is no consequence to be in a large town while you are reading. I read at New-Salem, which never had three hundred people living in it. The books, and your capacity for understanding them, are just the same in all places (Basler, 1953-1955, vol. 2, p. 328).

In 1858, Lincoln instructed James T. Thorton, to "read the books.... get a license, and go to the practice, and still keep reading" (Basler, 1953-1955, vol. 3, p. 344). In 1860, Lincoln wrote John M. Brockman, "the best mode of obtaining a thorough knowledge of the law is...only to get the books, and read them, and study them carefully... After reading it carefully through, say twice.... Work, work, work, is the main thing" (Basler, 1953-1955, vol. 4, p. 121). Lincoln's replies to these letters promote his non-traditional approach to education.

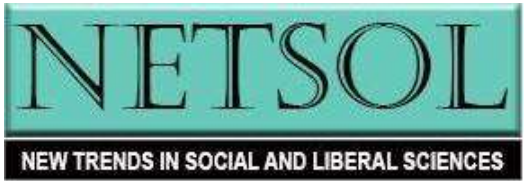




\section{Conclusion}

How can we use the information presented to proffer answers to the questions we initially posed? Surely, Lincoln was blessed with self-motivation, and he worked with available resources to educate himself. With no gym membership available in the wilderness, he took up wrestling. To Lincoln, a book damaged by water was preferable over having no book at all. Sans school sponsored field trips, he learned through observations and interactions with others. He joined organizations outside school settings as places to enrich his education. Lincoln understood that, on a variety of levels, education has the potential for improving the quality of life.

Lincoln's successful approach also underscores the primary importance of learning to read. Lincoln certainly understood the value of reading, because this skill made it possible for him to learn about many disciplines including U.S. History and the nation's founding documents, which led him to the study of law and a career in politics; arithmetic, which made him qualified to become a shop keeper and land surveyor; and science, which gave him a better understanding of the workings of the natural world. Alternatively, a student that can not read will find it next to impossible to master most disciplines.

Lincoln's biographical example also shows how people are different. They do not all fit neatly into the same mold. How did Lincoln accomplish so much with so little? First of all, he had parental support. Today, the importance of parental support remains paramount. Once given the opportunity to study, Lincoln built tremendously and continuously throughout his life on the basic foundation of reading, writing, and arithmetic skills that he secured during his youth. Was Lincoln an oddity? No. In fact, others, including Henry Clay, did the same.

"Listening to recall" and "Reading to Remember" were two extremely effective learning approaches for Lincoln. Memorizing and recitation from memory are often seen as negative in today's schooling. What is often lost with educators who oppose such practices is that higher level thinking cannot occur without basic content. For example, students must first learn the letters of the alphabet by rote before they can learn to read. Similarly, without a basic understanding of numbers, applying operations to them is impossible. Once students have learned the content, they may have an opportunity to reflect on, analyze, and examine what they learned and apply it to real world situations. In this respect, allowing students time for reflection of the material can serve as a great learning tool.

Too often, students are required to learn abstract arithmetic concepts without any realworld applications for those concepts. Then, educators wonder why they struggle to keep the students' interest. Education for its own sake is not enough. In order to be effective, education must have a purpose. Students must read, write, calculate, and think with an understanding of how these skills apply in their daily lives. Such an approach would foster student curiosity about the world and a proclivity for investigation. Change is constant and the best prepared people are those, like Lincoln, who are life-long learners.

Exploring the processes Lincoln experienced in securing a quality education may offer contemporary leaders a pathway for determining policies and defining requirements for the

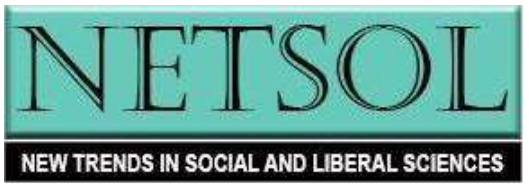


education of America's youth. It may also inform parents and taxpayers and help them rethink the "quality education" model. Perhaps, there is room in the educational system for different approaches including alternatives to the traditional public-school setting. While this biographical method cannot generate final answers to our questions, it may, in fact, reveal additional questions. Some of these may lead to looking more closely at various aspects of education only one aspect of which is schooling. The chief question that must be asked, however, is would Lincoln's peculiar learning style, including his non-sedentary reading habits, be embraced in a traditional classroom? Surely, options for securing a quality education for our students merit additional consideration.

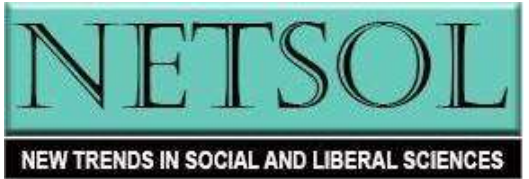




\section{References}

Basler, Roy P., ed. (1953-1955). The Collected Works of Abraham Lincoln. 9 vols. New Jersey: Rutgers University Press.

Bestor, Arthur E., Mearns, David, \& Daniels, Jonathan. (1963). Three Presidents and Their Books. Urbana: University of Illinois Press.

Beveridge, Albert J. Abraham Lincoln, 1809-1858. (1928). Boston: Houghton Mifflin Company.

Carpenter, F.B. (1995). The Inner Life of Abraham Lincoln: Six Months at the White House.

Rev. ed. Lincoln: University of Nebraska Press.

Cremin, Lawrence A. (1980). American Education: The National Experience, 1783-1876. New York: Harper \& Row.

Donald, David Herbert. (2001). Lincoln Reconsidered: Essays on the Civil War Era. New York: Vintage Books.

Dunlap, Lloyd A. (1959). “Lincoln’s Sum Book.” Lincoln Herald LXI (Spring): 6-10.

Dorfman, Maurice. (1966). “Lincoln’s Arithmetic Education: Influence on His Life.” Lincoln Herald LVIII (Summer): 61-80.

Fehrenbacher, Don E. and Virginia Fehrenbacher, eds. (1996). Recollected Words of Abraham Lincoln. Stanford: Stanford University Press.

Hunt, Draper H. (1986). "Educating a President: Abraham Lincoln and Learning, 1809-1854." Lincoln Herald 88, no. 3 (September): 106-114.

McPherson, James M. Abraham Lincoln. (2009). Oxford: Oxford University Press.

Merry, Robert W. (2012). Where They Stand: The American Presidents in the Eyes of Voters and Historians. New York: Simon \& Schuster, Inc.

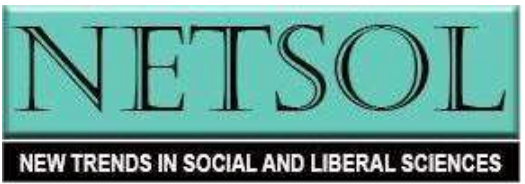


Neely, Mark E. Jr. (1982). The Abraham Lincoln Encyclopedia. New York: McGraw Hill Book Company.

Oates, Stephen B., ed. (1986). Biography as High Adventure: Life Writers Speak on Their Art. Amherst: The University of Massachusetts Press.

Oates, Stephen B. (1990). Biography as History. Waco, Texas: Baylor University.

Owens, Delia. (2018). Where the Crawdads Sing. New York: G.P. Putnam's Sons.

Warren, Louis A. (1991). Lincoln's Youth, Indiana Years, 1816-1830. Indianapolis: Indiana Historical Society.

Westover, Tara. (2018). Educated: A Memoir. New York: Random House.

Wills, Gary. (1992). Lincoln at Gettysburg: The Words that Remade America. New York: Simon \& Schuster.

Wilson, Douglas L. (1991). “What Jefferson and Lincoln Read.” Atlantic Monthly CCLXVII (January): 51-62.

Wilson, Douglas L. and Rodney O. Davis. (1998). Herndon's Informants: Letters, Interviews, and Statements about Abraham Lincoln. Chicago: University of Illinois Press.

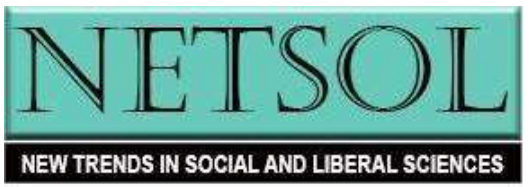

